\title{
Explicatio and ratio naturae. Medieval Understandings of the Origin of the Universe. Universidad de Navarra, Pamplona (Spain), 16 January 2018. Organiser: Maria Jesús Soto-Bruna (Universi- dad de Navarra)
}

Cosmology has been always a major branch of philosophical inquiry. In this respect, late antiquity and medieval approaches to the origin, structure, and fate of reality were particularly rich and they exerted a remarkable influence, at least until 1687, with the publication of Sir Isaac Newton's Philosophiae naturalis principia mathematica. Bearing this in mind, the one-day conference «Explicatio and ratio naturae. Medieval Understandings of the Origin of the Universe», organized by Professor María Jesús Soto-Bruna as one of the final activities of her projects «Unity and Plurality of the Logos in the World. Explicatio and ratio naturae $\left(4^{\text {th }}-14^{\text {th }}\right)$. Medieval Hermeneutics» (MINECO $\mathrm{n}^{\circ}$ ref.: FFI2015-663947P), and «Unity and Plurality. Metaphysics of the Logos in Medieval Explanations Regarding the Rationality of Nature» (PIUNA ref.: 2015-24), delved into the metaphysical question of the explicative causality of the Logos, as it was examined and answered in the Middle Ages, and shed some light on the perennial problem of the relationship between the one and the multiple. In this way, this event constituted a progress in the knowledge of patristics and medieval insights about the rationality of the nature.

The meeting opened with Prof FranCISCO O'REILly, from the University of Montevideo and author of «Causality, Flux and Procession. An Unexpected Encounter between Proclus, Eriugena, and Avicenna», discussing the notion of creation, namely, the origin of everything from nothingness, as it is presented in the Liber de Causis primis et secundis ( $13^{\text {th }}$ century), wrongly attributed to Avicenna. In this eclectic work we find a mixture of the ideas of Proclus ( $5^{\text {th }}$ century), at least as they appear in the apocryphal Liber de Causis or Liber de bonitate pura, Eriugena ( $9^{\text {th }}$ century), and the aforementioned Avicenna ( $10^{\text {th }}$ century). The Liber de Causis primis et secundis develops an interesting sophiology in which God's causality, at the eternal moment of creation, flows through the causae primordiales created in the Logos. By doing this, the unknown author of this work clearly appears as a follower of Proclus and we also can trace from him the influence of Eriugena's Periphyseon. However, as O'Reilly argued, Avicenna's theory of causality is essential, in the context of the work, to move away more radically from any shadow of pantheism.

Immediately after O'Reilly's presentation came Prof LAURA CORSO DE ESTRADA from the Pontifical Catholic University of Argentina. With her work, titled «Ciceronian Tradition of ius naturae in the Diffusive Way of bonum: Philip the Chancellor's Reading», Corso, without leaving the metaphysical point of view, made a turn to a more anthropological perspective. The, so to speak, Neoplatonic dogma bonum est diffusivum sui should not be understood only in cosmological terms but it also must be recognized in the intimate nature of men. Thus, in the second part of his Summa, Philip the Chancellor $\left(13^{\text {th }}\right.$ century) highlights how the right exercise of free will of men constitutes a form of diffusion of goodness, relying for this task, as Corso showed, on the long Ciceronian tradition of ius naturae.

The third presentation of the day, «Harmony in the Conception of the Universe. Unity and Plurality in Eriugena», delivered by Prof MARÍA JESÚS SOTO-BRUNA from the University of Navarra, brought again the thought of the Carolingian master to the foreground. In continuity with O'Reilly's thesis, SotoBruna also studied the use of the term processio in Eriugena's account of divine creation, following the argumentation as presented in the Divisione naturae. For her, this technical word comprises in Eriugena two core dimensions of the created reality, that is, its hierarchical structure and the correspondent unity underlying it, which is perceived as harmony, or the order between the levels. At the conclusion of her speech, the Spanish academic highlighted some mysterious issue in this explanation of creation: for the protected of Charles the Bald, creation does not imply something that does not already exists in the One, so it becomes necessary to think how is possible to affirm the presence of some kind of multiplicity in the absolute unity of God. 
The morning session finalized in the thirteenth century, with the intervention of Prof ISABEL LEÓN, from the Faculty of Theology of the University of Navarra and who was recently granted the Marco Arosio Award for her doctoral thesis on Saint Bonaventure ( $13^{\text {th }}$ century). Her paper entitled «The Creator Mediation of the Verb, Origin of the Creature's Expressive Beauty in St. Bonaventure» was a reflection about the role, assigned by the Seraphic Doctor, of the second person of the Holy Trinity as mediator in the origin of creation. Thus, the Logos is understood as a word eternally pronounced and which embraces the most intimate and deep truth of creatures and, at the same time, manifests, in some way, the transcendence of God, the artifex of everything.

The afternoon's session was thematically more varied. The fifth presentation of the day was delivered by Dr Pilar Herráiz Oliva, researcher at the Istanbul Medeniyet University. Her work «On the De aeternitate mundi in Averroes and Averroism», also remaining in the thirteenth century, exposed the problems that arose in that time with some interpretations of Averroes $\left(12^{\text {th }}\right.$ century) concerning the question about the possibility of the eternity of the created world. The issue, as Herráiz Oliva suggested, deals from the beginning with a core methodological topic, i.e. the independent character of the contents of faith and reason, and, in consequence, with the relationship between philosophy and theology, with the primacy of the last one. Subsequently, how can we rationally discuss the eternity of the world if revelation teaches us that creation is ex nihilo and occurs at the beginning of all times? To answer this, the academic focused on two representatives of the so called Averroism: Siger of Brabant and Boethius of Dacia, demonstrating that in stricto sensu they were not following Averroes as such, or at least that there was not a unanimous interpretation of the Andalusian philosopher. Accordingly, the necessity of a reappraisal of the category of Averroist. not just limited in reference to the origin of the world but more widely.

The next speaker was Dr Nicola POLLONI, Alexander von Humbold Research Fellow at the Humboldt University of Berlin. The Italian academic, through his talk «Dominicus Gundissalinus and Daniel of Morley on Establishing and Conserving Causality of the Universe», introduced us to the littleknown figure Daniel of Morley (12 $2^{\text {th }}$ century). This interesting character travelled to Toledo in order to get in contact with the large translations, from Greek and Arab to Latin, made there at that epoch, coinciding in the same location with Dominicus Gundissalinus. Polloni provided a precise comparative analysis of, mainly, Gundissalinus' De processione mundi and Morley's Philosophia, both works primarily focused in cosmological explanations. He concluded that there is a gap between them because while the first one concentrates his efforts on a more metaphysical approach, the latter one makes more use of natural writings. On the other hand, in the intellectual environment of the twelfth century, the primordial chaos presented in the Timaeus was part of the paradigmatic explanation of creation. In this sense, another key difference between these two authors lies in this point. In De processione mundi Gundissalinus rejects the theory of primordial chaos, in correspondence with his attempt to highlight the creatio ex nihilo. For his part, Daniel of Morley embraces that theory and analyses the origin of first matter and primordial chaos from a perspective profoundly influenced by William of Conches $\left(12^{\text {th }}\right.$ century). This discussion leads to a diversity of answers for the topic of primary and secondary causality on the establishment of the created universe, namely, the derivation of multiplicity from the One.

The meeting was closed by Prof AgNiEszKA KiJEwSKA, Professor at the Department of the History of Philosophy of the Catholic University of Lublin. With her, we were guided as if we were following the Neoplatonic scheme mone - proodos - epistrophe, at the end we returned to the very beginnings of the Middle Ages, that is to say, to the Father of the Grace. Kijewska's presentation «The Path of Mystical Experience in Augustine» made us aware of the nature of created reality as a sign, establishing then a semiotic apprehension of it. If reality is a sign, then it requires an interpreter who receives and decodes it, which implicitly affirms the will of its author to produce it. One of these interpreters is the man, who should try with all his intellectual capacity, and during all his life, to reach out the true meaning of every creature, and with this to know better of God. Through this particular dynamic, men are capable of having 
a primary experience, a personal and psychological one, of the divinity. Human intellect finds out the active presence of the divine nature in creation. Therefore, the first experience that men have from God comes from the created world. But the world is not the unique semiotic revelation of God, he also manifests himself through the Sacred Scriptures and the Incarnation of his Son. So, Kijewska added, for Augustine the human effort alone appears insufficient at the moment of travel the path to the mystical experience, and it should be necessarily open to transcendence and mystery.

This remarkable event constituted an important contribution to the contemporary research on medieval interpretations of the origin of the world. The conference spanned a long period of time without losing the necessary depth of advanced research. This was possible due to the congregation of leading academics from different parts of the world (Argentina, Poland, Spain, Uruguay, and Germany) working together in order to improve and enhance our knowledge of medieval apprehensions of the deployment of the Logos in the world at the unique and eternal moment of creation. Furthermore, this meeting keeps continuity with the previous projects of its organizer, Professor Soto-Bruna, namely, «Universitas rerum and Metaphysics of the Logos in the Medieval Neoplatonic Interpretation of the emanative-manifestative process of causality. From E. Eriugena to M. Eckhart» (FFI2011-28729), «The notions of causality and manifestation as explicatio mundi. From Scotus Eriugena to M. Eckhart» (FF/2008-02804/FISO Ministry of Science and Innovation), «De Processione Mundi, Dominicus Gundissalinus (s. XII)» (MECDGICYT - TXT 99-1287), and «Neoplatonism and Causality in the first Metaphysics written in Spain (Avicebron, $11^{\text {th }}-$ Gundissalinus, 12 $2^{\text {th }}$ ) and their European Projection» (HUM2004-00983/FISO). The combined efforts of scholars in this conference showed us that there remains much work to do in this field. The medieval period is an inexhaustible source of knowledge, impossible to encompass for an isolated academic, which is why collaborative initiatives like this event are essential to break through and discover further secrets.

RODRIGO BALLON VILLANUEVA

University of Navarra 